\title{
Fresco Paintings Deterioration: Case Study of Bodjani Monastery, Serbia
}

Snežana Vučetić ${ }^{1}$, Jonjaua Ranogajec ${ }^{1}$, Slavica Vujović ${ }^{2}$, Snežana Pašalić ${ }^{3}$, John Milan van der Bergh ${ }^{1}$, Bojan Miljević ${ }^{1}$

1. University of Novi Sad - Faculty of Technology, Laboratory for Materials in Cultural Heritage, Novi Sad, Serbia

2. Institute for Protection of Cultural Monuments of the Autonomous Province of Vojvodina, Petrovaradin, Serbia

3. University of Belgrade, Vinča Institute of Nuclear Sciences, Belgrade, Serbia

The Bodjani (Bođani) Monastery is a Serbian national heritage of great significance. It was founded in 1478 and devoted to Virgin Mary. It was razed by the Ottomans, rebuilt, and destroyed again during the Rakoczi's War of Independence (1703-11). Present church was built in 1722 in the Baroque style and painted by South Slavic painter Hristofor Zhefarovich (Hristofor Žefarović). The church is a unique architectural entity and represents one of the places where Serbian modern fresco art was born. Regarding the style, the church of Bodjani Monastery represents an architectural transition from the late Byzantine to the new Baroque architectural concept for Orthodox Christian temples [1].

The Monastery lies in moderate continental climatic conditions on clayey and sandy soil. The Monastery is at risk as it is situated close to the Danube River, on soil greatly affected by underground water. Constant humidity and the consequent crystallization of salts on the painted surfaces are the main reasons for flaking and pulverization of the painted layer (Figure 1), appearing mostly in the lower area up to a height of $3 \mathrm{~m}$ (10 ft.). The church had only the system of air isolation of the walls and since 1974 the system for active electro-osmosis was also installed. However, over the years, these systems were not maintained, which affected ongoing destruction of the walls and the painted layers. The monastery is still in operation today, but its maintenance is not adequate considering its significance.

The results presented in this paper are manly concentrated on the chemical-mineralogical and textural characterization of the bricks collected from the Bodjani Monastery church, in order to investigate the existing correlation between the raw materials composition and their disintegration due to the water absorption-moisture action and salt crystallization process. The final goal was to identify the degree of destruction of the examined materials, which presents the essential background for the future procedures of restoration. The northern wall represents the most damaged part of the Bodjani Monastery. The examined materials were samples of salt crystals and the indoor bricks, collected from the northern wall below the fresco layer, from the same area and on the same height. The samples were taken from the already damaged areas (Figure 1b). Methods used for the characterization of the indoor brick samples were X-Ray Diffraction Analysis (XRD), Scanning Electron Microscopy with Energy Dispersive Spectroscopy (SEM-EDS), Differential Thermal Analysis/Thermogravimetry and $\mathrm{Hg}$ Intrusion Porosimetry. The salt samples were investigated using Ion Chromatography (IC), and SEM-EDS, and the environmental monitoring - temperature and relative humidity were recorded by data loggers during the period of 11 months.

Based on the obtained results, presence of sodium sulfate was identified. Considering the environmental conditions on the sampling day $\left(\mathrm{T}=15^{\circ} \mathrm{C} / 59^{\circ} \mathrm{F}\right.$ and $\left.\mathrm{RH}=71 \%\right)$, it could be assumed that the stable phase which crystallizes is mirabilite, but SEM investigation showed that the morphology of the salt 
crystals collected from the wall surface matches that of thenardite (Figure 2). Indoor brick samples collected from the same height below the fresco layer are ceramic products based on mineralogical forms: quartz, feldspar, calcite, mica and dolomite, originating from raw material mixture. There are collected two types of brick samples visibly different in their condition: ones are with good mechanical properties, while others are crumbling. The DTA/TG analysis confirmed that the crumbling brick samples were fired at a lower temperature - about $500^{\circ} \mathrm{C} / 932^{\circ} \mathrm{F}$, while the brick samples with good mechanical properties were fired below $800^{\circ} \mathrm{C} / 1472^{\circ} \mathrm{F}$, which explains difference in their state. The interval of pore radius ( $\mathrm{Hg}$ porosimetry) and differences between mass $\%$ of $\mathrm{Na}^{+}$ions (EDS and IC) also explain the poor mechanical characteristics of the crumbling brick samples and visible salt crystallization on their surface as a consequence of structure destruction $[2,3]$.

The results presented in this paper clearly show that deterioration of fresco paintings cannot be understood without holistic approach and taking into account the interactions among microclimate, location of salt crystallization and origin of the salt ions and raw materials used for production of constitutive materials. Better understanding of the salt crystallization mechanisms (transition between thenardite and mirabilite, as well as thenardite reprecipitation) could be essential background for future restoration procedures of the Bodjani Monastery and other similar monuments[4].
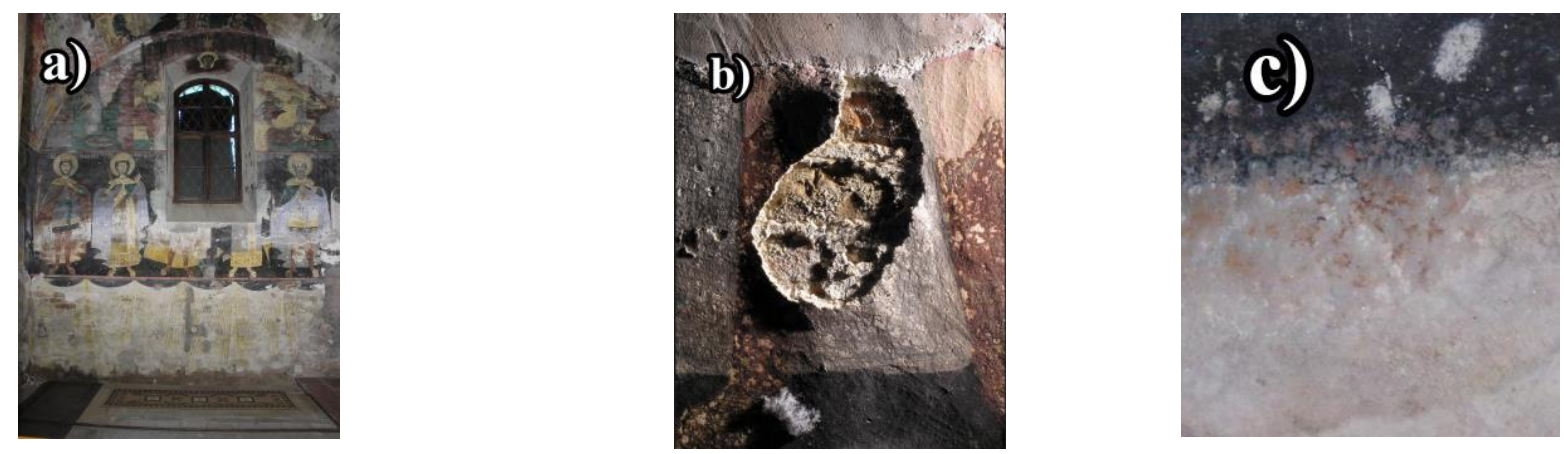

Figure 1. The view of Hristofor Zhefarovich fresco painting in Bodjani Monastery: a) northern wall; b) pulverization and crumbling of fresco paintings; c) salt crystallization on the fresco paintings surface

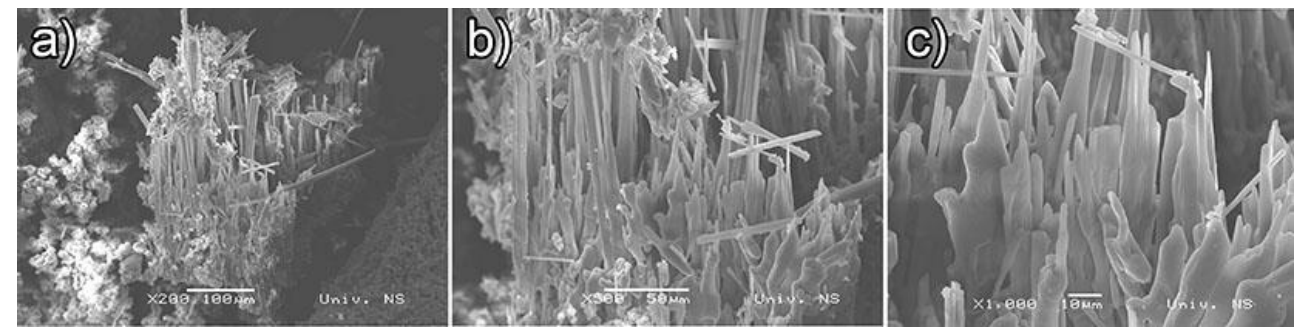

Figure 2. SEM images of salt crystals on the crumbling brick sample a) x200, b) x300 c) x1000.

References:

[1] Lj. Stošić in "The Monastery of Bodjani”, (Institute for Protection of Cultural Monuments of the Autonomous Province of Vojvodina, Petrovaradin and Platoneum, Novi Sad)

[2] N. Tsui, R. Flatt and G Scherer, Journal of Cultural Heritage 4 (2003) pp. 109-115

[3] H. Roesch and H.J. Schwarz, Studies in Conservation 38 (1993) pp. 224-230

[4] Financial support from the Serbian Ministry of Education, Science and Technological Development (Contract No. III45008) is gratefully acknowledged. 